\title{
Comparison of internal organ injuries by blunt abdominal trauma in rats with empty or full stomach
}

\author{
Hüseyin Kafadar, M.D., ${ }^{1}$ Safiye Kafadar, M.D., ${ }^{2}$ Mehmet Tokdemir, M.D. ${ }^{3}$ \\ ${ }^{1}$ Regional Center, The Council of Forensic Medicine, The Ministry of Justice, Elazığ; \\ ${ }^{2}$ Elazığ Pricipal Medical Center, Elazığ; \\ ${ }^{3}$ Department of Foresic Medicine, Fırat University Faculty of Medicine, Elazığ
}

\begin{abstract}
BACKGROUND: The aim of the study was to investigate if there was a difference in injury in intra-abdominal viscera due to blunt abdominal trauma sustained by rats with empty or full stomach and to examine which viscera is affected most, based on the direction of the trauma.

METHODS: Since there is no data in the literature on the force of trauma, a pilot study was carried out before commencing the experimental study. An apparatus was built to determine the trauma force that would not cause sudden death, and rats were allowed free fall from a height of 40 and $45 \mathrm{~cm}$ so that they would land on their abdomen. The most appropriate force of trauma $(F=69.978 \mathrm{~N})$ and absorbed energy $\left(E=1 / 2 \mathrm{mv}^{2}=0.979\right.$ Joules) were obtained in rats weighing $250 \mathrm{~g}$ that fell from a height of $40 \mathrm{~cm}$.
\end{abstract}

RESULTS: Thirty six rats were included in the study and separated into six groups. Any statistically significant differences between groups with regard to the stomach being empty or full during trauma and its direction were examined (anterior, right/left sided).

CONCLUSION: It was observed that there were differences in injuries sustained by the internal organs depending on the fullness or emptiness of the stomach and the direction of the trauma.

Key words: Blunt abdominal trauma; forensic medicine; rat; trauma.

\section{INTRODUCTION}

Trauma, one of the most common causes of death in developed countries worldwide, ${ }^{[1-3]}$ is the major reason for death between the ages of $\mathrm{I}$ and 44. It is the third most common cause of death for people of all ages. ${ }^{[4,5]}$

The majority of the population (81.8\%) is between 0 and 44 years of age in Turkey, and therefore, most of the population is in the risk group for trauma. The most common cause of traumatic death in Turkey is traffic accidents, followed by occupational injuries. ${ }^{[6]}$

Some abdominal organs are mobile, whereas the position of

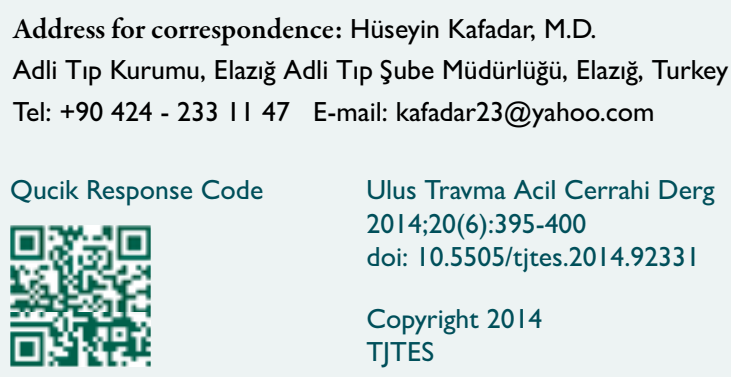

some is fixed in the body. Organ injuries from blunt trauma to the abdomen vary depending on the relative mobility of the organs. The rate of injury is higher in fixed-position organs compared to the mobile organs in the abdomen. Injuries to organs containing spaces, air, and fluids, such as the gastrointestinal system organs, occur through different mechanisms than injuries to solid organs such as the liver. For instance, blunt trauma to the epigastric area, or the left upper abdominal region, may push the stomach to the back of the abdomen and against the vertebrae, and thus, cause contusion to the stomach. Although blunt trauma rarely causes perforation of the stomach when the stomach is empty, the effects of a similar trauma differ on a full stomach. When the stomach is full, sudden traumatic force generates a hydrostatic pressure transferred by the fluid contents to every point of the stomach, leading to rupture of the stomach. ${ }^{[7]}$

Blunt trauma to the abdomen most commonly causes organ damage in the spleen, liver, mesenterium, and small intestines, respectively. ${ }^{[8]}$

In this study, we aimed to experimentally determine whether there were any differences in internal organ damage due to blunt trauma to the abdomen in rats with a full or empty stomach. 


\section{MATERIALS AND METHODS}

The study included ten-week-old thirty-six rats having a mean weight of 150-250 g. Rats were purchased from the animal laboratory of Elazig University. This study was approved by the ethics committee and performed following the ethical rules for animal experiments.

There was no previous literature to review for the rate of traumatic force to apply on rats. Therefore, a pilot study was performed following the methodological procedures described by Özel et al. ${ }^{[9]}$ The degree of traumatic force (newton) not causing sudden death but leading to internal organ damage, and the energy (joule) absorbed by rats were determined.

The formulations used to calculate energy in this study are listed below:

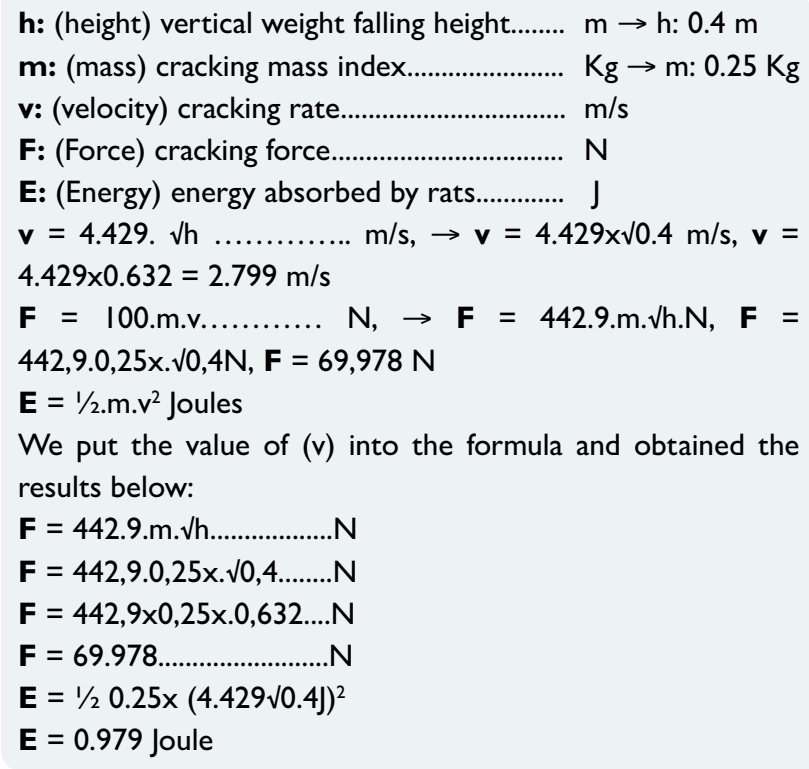

To determine a measurable traumatic force, rats whose weight ranged from 200 to $250 \mathrm{~g}$ were dropped from a height of 40 and $45 \mathrm{~cm}$ to hit the abdominal region in a pre-prepared experimental assembly suggested by Özel et al..9] (Figure I). The most convenient traumatic force $(F=69.978 \mathrm{~N})$ and rate of absorbed energy ( $E=0.979$ Joules $)$ in rats were determined by testing with a material that was $250 \mathrm{~g}$ in weight and dropping it from a height of $40 \mathrm{~cm}$.

Rats were starved for 24 hours. Afterwards, eighteen rats were fed regarding their daily routine. By using this approach, rats were separated into two groups: rats with a full stomach $(n=18)$ and rats with an empty stomach $(n=18)$. After the feeding period, six rats from each group were traumatized from either the anterior, left, or right. Rats were separated into six groups depending on their stomach conditions and the location of the trauma (Table I). Rats with empty stomachs were divided into three groups regarding whether they were traumatized from the anterior (Group I), the right
(Group 2) or the left (Group 3) (Table I). Similarly, rats with full stomachs were categorized into three groups (Groups 4, 5 , or 6) depending on the location of the trauma, from either the anterior, the right, or the left, respectively (Table I).

Rats were anesthetized with ketamine and taken to an assembly previously prepared to produce blunt trauma on the abdomen by allowing free falling of rats in frictionless conditions (Figure I).

A material which was $250 \mathrm{~g}$ in weight was applied on rats by free falling of the material from $40 \mathrm{~cm}$ height to produce blunt injury on the abdomen. After 30 minutes, rats were decapitated. Any injury on solid and hollow organs of the abdomen was macroscopically examined by an autopsy of rats in the department of forensic medicine in Elazig University.

After blunt injury was produced on rat abdomens, any differences in intra-abdominal solid and hollow organ damage were checked in order to ascertain whether full or empty stomach constituted a difference and whether the rats were traumatized from the anterior, or the right or left side.

Data was calculated by average, standard error, and mean. Non-parametric statistical tests, including the Kruskal-Wallis $\mathrm{H}$ test and the Mann-Whitney $U$-test, were used for statistical analysis of data. Statistically significant $P$ values less than $0.05(p<0.05)$. The SPSS 15.0 for Windows pocket program was used for statistical analysis.

\section{RESULTS}

In this study, the frequency of injury on intra-abdominal organs was determined to be highest in liver, followed by spleen and small intestine, respectively (Table I).

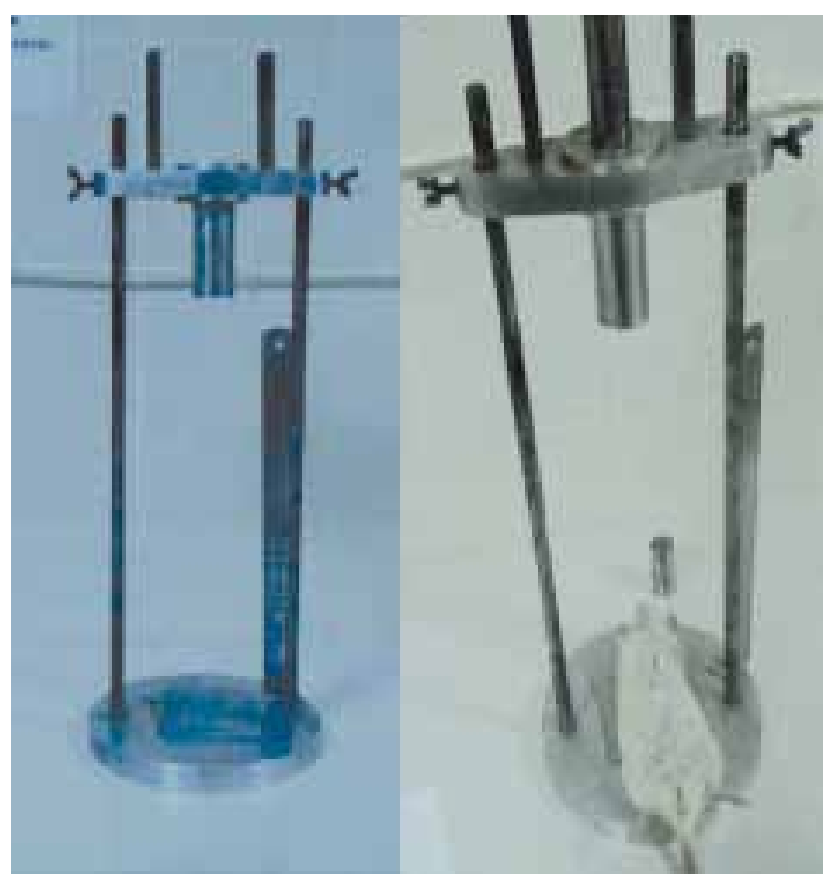

Figure 1. Illustration of assembly prepared for producing trauma. ${ }^{[9]}$ 
Table I. Schematic demonstration of rats' groupings according to the fullness of the stomach and direction of trauma

\begin{tabular}{|c|c|c|c|c|c|c|c|c|c|}
\hline Groups & & $\mathbf{L}$ & $S$ & $\mathbf{R K}^{*}$ & $\mathbf{L K}^{*}$ & PANK* & Sto* & SI* & $\mathbf{L I}^{*}$ \\
\hline \multirow[t]{4}{*}{ I } & $\mathrm{n}$ & 6 & 6 & 6 & 6 & 6 & 6 & 6 & 6 \\
\hline & Hydrangea & 4.166 & 2.166 & 0.5 & 0.5 & 0.5 & 0.166 & 0.5 & 0.333 \\
\hline & st. deviation & 0.752 & $\left.1.47\right|^{\mathrm{e}}$ & 0.836 & 0.836 & 1.224 & 0.408 & 0.836 & 0.816 \\
\hline & Avarage & $4^{\mathrm{a}}$ & 2.5 & 0 & 0 & 0 & 0 & 0 & 0 \\
\hline \multirow[t]{4}{*}{2} & $\mathrm{n}$ & 6 & 6 & 6 & 6 & 6 & 6 & 6 & 6 \\
\hline & Hydrangea & 4.333 & 1 & 1.333 & 0.166 & 0 & 0 & 0.5 & 0 \\
\hline & st. deviation & 0.816 & 0.894 & 1.211 & 0.408 & 0 & 0 & 0.836 & 0 \\
\hline & Avarage & $4.5^{b}$ & $\mathrm{If}^{\mathrm{f}}$ & 1.5 & 0 & 0 & 0 & 0 & 0 \\
\hline \multirow[t]{4}{*}{3} & $\mathrm{n}$ & 6 & 6 & 6 & 6 & 6 & 6 & 6 & 6 \\
\hline & Hydrangea & 1.166 & 2.833 & 0.166 & I & 0.166 & 0 & 0.5 & 0.5 \\
\hline & st. deviation & 0.983 & 1.169 & 0.408 & 1.264 & 0.408 & 0 & 0.836 & 0.836 \\
\hline & Avarage & $1.5^{\mathrm{d}}$ & $3^{c}$ & 0 & 0.5 & 0 & 0 & 0 & 0 \\
\hline \multirow[t]{4}{*}{4} & $\mathrm{n}$ & 6 & 6 & 6 & 6 & 6 & 6 & 6 & 6 \\
\hline & Hydrangea & 2.166 & 0.833 & 0.166 & 0.166 & 0 & 1.166 & 1.166 & 0.333 \\
\hline & st. deviation & $1.47 \mid$ & 0.752 & 0.408 & 0.408 & 0 & 1.169 & 1.602 & 0.816 \\
\hline & Avarage & 2.5 & 1 & 0 & 0 & 0 & 1 & 0.5 & 0 \\
\hline \multirow[t]{4}{*}{5} & $\mathrm{n}$ & 6 & 6 & 6 & 6 & 6 & 6 & 6 & 6 \\
\hline & Hydrangea & 2.166 & 0.5 & 0.5 & 0 & 0 & 0.166 & 0.333 & 0.333 \\
\hline & st. deviation & $1.47 \mid$ & 0.836 & 0.836 & 0 & 0 & 0.408 & 0.516 & 0.816 \\
\hline & Avarage & 2.5 & 0 & 0 & 0 & 0 & 0 & 0 & 0 \\
\hline \multirow[t]{4}{*}{6} & $\mathrm{n}$ & 6 & 6 & 6 & 6 & 6 & 6 & 6 & 6 \\
\hline & Hydrangea & 0.5 & 1.333 & 0 & 0.833 & 0 & 0.666 & 0.5 & 0.5 \\
\hline & st. deviation & 0.836 & 0.816 & 0 & 0.983 & 0 & 0.816 & 0.836 & 0.836 \\
\hline & Avarage & 0 & 1.5 & 0 & 0.5 & 0 & 0.5 & 0 & 0 \\
\hline \multirow[t]{5}{*}{ Total } & $\mathrm{n}$ & 36 & 36 & 36 & 36 & 36 & 36 & 36 & 36 \\
\hline & Hydrangea & 2.416 & 1.444 & 0.444 & 0.444 & 0.111 & 0.361 & 0.583 & 0.333 \\
\hline & st. deviation & 1.762 & 1.252 & 0.808 & 0.808 & 0.522 & 0.723 & 0.937 & 0.717 \\
\hline & Avarage & 2.5 & I & 0 & 0 & 0 & 0 & 0 & 0 \\
\hline & $\mathrm{p}$-value & $<0.001$ & 0.018 & 0.112 & 0.240 & 0.532 & 0.030 & 0.950 & 0.764 \\
\hline
\end{tabular}

a: Difference between Groups I and 4 is significant; b: Difference between Groups 2 and 5 is significant; c: Difference between Groups 3 and 6 is significant ( $p<0.05$ ); $d$ : Difference between Group s3 and 6 is not remarkable; e: Difference between Groups I and 4 is not remarkable; f: Difference between Groups 2 and 5 is not remarkable ( $>$ >0.05); *: Differences between Groups I and 4, Groups 2 and 5, or Groups 3 and 6 are not remarkable when considering injuries of the right kidney (RK), the left kidney (LK), the pancreas (PANK), the small intestine (SI), the large intestine (LI), the stomach (Sto), and the liver (L).

When considering liver, spleen, and stomach injuries, differences between the groups were statistically significant $(p<0.05)$. However, the rate of damage on other organs was not significantly different (Table I).

Enhancement in the number and grade of solid organ injuries was determined in groups with the empty stomach (Table I). An enhanced gastrointestinal tract injury was observed in rats with a full stomach; however, this difference was not statistically remarkable (Table I).

Frequency of damage to the liver differed depending on the direction of trauma and the condition of the stomach. Liver was most frequently injured by trauma from the right (Table I). When comparing the frequency of liver injury between rats injured from the anterior (Groups I and 4) or from the right (Groups 2 and 5), a statistically significant difference was found $(p=0.017$ and $p=0.014$, respectively), while change between rats that were traumatized from the left side (Groups 3 and 6) was not remarkable $(p=0.22)$ (Tables $I$ and 2 , Figures 2 and 3 ).

Due to blunt trauma, injury was observed especially on the right lobe of the liver. The most frequent complication was determined as a subcapular hematoma, which was followed by laceration of the liver and, less frequently, by deep parenchymal injury.

Spleen was observed to be the second most frequently injured organ in blunt abdominal trauma (BAT). Spleen was most frequently injured by trauma from the left. A significant difference 
Table 2. Frequency of injuries to intra-abdominal solid or hollow organs with regard to groups

\begin{tabular}{|c|c|c|c|c|c|c|c|}
\hline & Groups & $\mathbf{n}$ & Average order & & Groups & $\mathbf{n}$ & Average order \\
\hline \multirow[t]{6}{*}{ Liver } & I & 6 & 28.92 & PANK & I & 6 & 20.58 \\
\hline & 2 & 6 & 29.92 & & 2 & 6 & 17.5 \\
\hline & 3 & 6 & II & & 3 & 6 & 20.42 \\
\hline & 4 & 6 & 16.92 & & 4 & 6 & 17.5 \\
\hline & 5 & 6 & 16.92 & & 5 & 6 & 17.5 \\
\hline & 6 & 6 & 7.33 & & 6 & 6 & 17.5 \\
\hline Total & & 36 & & Total & & 36 & \\
\hline \multirow[t]{6}{*}{ Spleen } & I & 6 & 24 & Stomach & I & 6 & 16.75 \\
\hline & 2 & 6 & 15.33 & & 2 & 6 & 14 \\
\hline & 3 & 6 & 28.92 & & 3 & 6 & 14 \\
\hline & 4 & 6 & 13.75 & & 4 & 6 & 26.58 \\
\hline & 5 & 6 & 10.42 & & 5 & 6 & 16.75 \\
\hline & 6 & 6 & 18.58 & & 6 & 6 & 22.92 \\
\hline Total & & 36 & & Total & & 36 & \\
\hline \multirow[t]{6}{*}{ RK } & 1 & 6 & 19.42 & SI & I & 6 & 18 \\
\hline & 2 & 6 & 26.5 & & 2 & 6 & 18 \\
\hline & 3 & 6 & 16.08 & & 3 & 6 & 18 \\
\hline & 4 & 6 & 16.08 & & 4 & 6 & 22 \\
\hline & 5 & 6 & 19.42 & & 5 & 6 & 17 \\
\hline & 6 & 6 & 13.5 & & 6 & 6 & 18 \\
\hline Total & & 36 & & Total & & 36 & \\
\hline \multirow[t]{6}{*}{ LK } & I & 6 & 19.42 & LI & I & 6 & 18.17 \\
\hline & 2 & 6 & 16.08 & & 2 & 6 & 15 \\
\hline & 3 & 6 & 23.17 & & 3 & 6 & 20.75 \\
\hline & 4 & 6 & 16.08 & & 4 & 6 & 18.17 \\
\hline & 5 & 6 & 13.5 & & 5 & 6 & 18.17 \\
\hline & 6 & 6 & 22.75 & & 6 & 6 & 20.75 \\
\hline Total & & 36 & & Total & & 36 & \\
\hline
\end{tabular}

L: The liver; RK: The right kidney; LK: The left kidney; PANK: The pancreas; SI: The small intestine; LI: The large intestine.

was observed between rats that were traumatized from the left side (Groups 3 and 6) ( $p=0.018)$ (Tables I and 2).

Injuries to the gastrointestinal tract were mostly observed on the mesenterium or serosa as a hematoma and crush. Perforation in the gastrointestinal system (GIS) was not observed in rats.

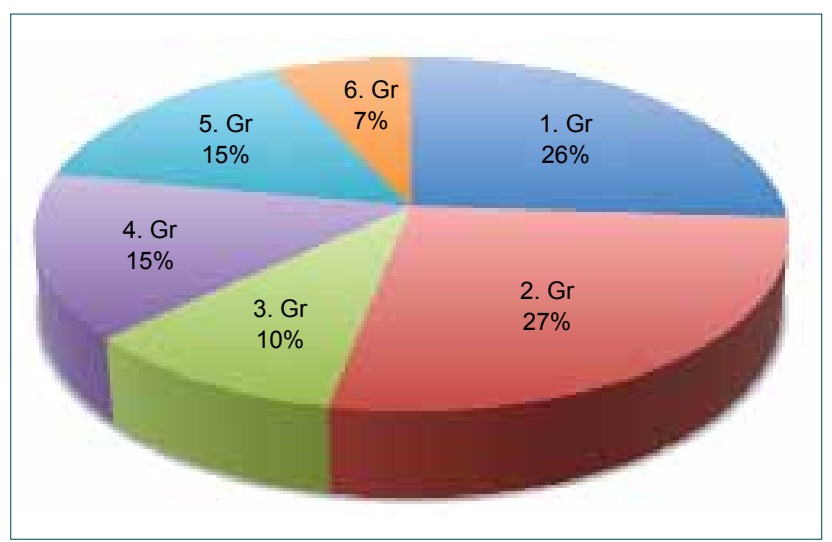

Figure 2. Distribution of lesions on the liver by group.
On the other hand, although there was a difference between groups with respect to kidney and pancreas injuries produced by BAT, when the direction of trauma or the fullness of the stomach was considered, it was not statistically significant $(p>0.05)$.

In this study, a model was developed and the force of BAT

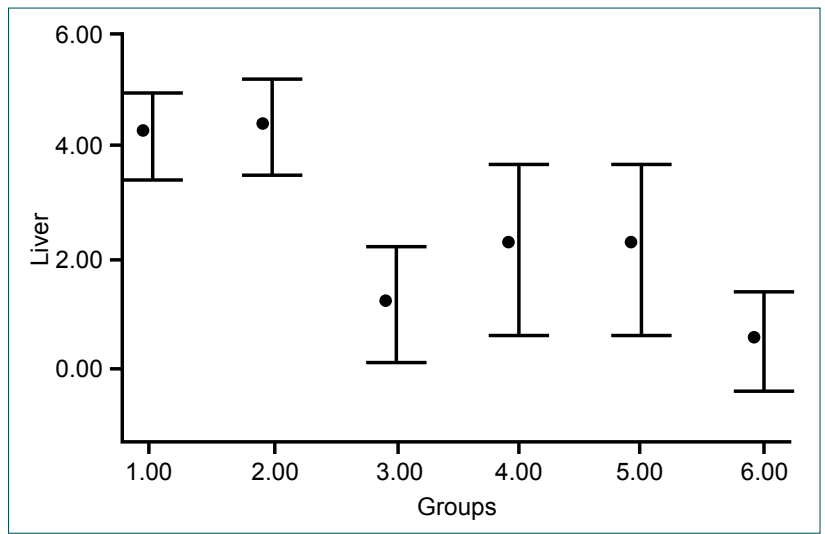

Figure 3. Distribution of lesions on the liver by group. 
which would not cause sudden death in rats but would lead to intra-abdominal organ injuries was determined. The frequency and grade of intra-abdominal organ damage involving preventable death due to BAT were aimed to be determined.

\section{DISCUSSION}

Injuries are most commonly seen on the head, the extremities, and thirdly on the abdomen. Organ damage is usually caused by blunt trauma. ${ }^{[1-3]}$ Abdominal traumas, which are either penetrating or blunt, result in severe morbidity or mortality. Blunt trauma generally leading to multisystem organ injuries is usually diagnosed late due to its complexity. Although the type of trauma to the abdomen may be either penetrating or blunt, patients die due to abdominal trauma for two reasons: hypovolemic shock, or peritonitis and septic shock due to injuries to intra-abdominal hollow organs. Two percent of patients reaching the hospital alive after blunt trauma develop hemorrhage causing death. Undiagnosed intra-abdominal organ injury is the number one preventable cause of death due to trauma. ${ }^{[10,11]}$

Liver is the most commonly injured intra-abdominal organ due to BAT caused by traffic accidents. There is no consensus on the mechanisms of liver injury yet. It has been suggested that liver injury could be caused by a crush, crack, or displacement of the liver due to a crash, in addition to liver damage due to the effects of acceleration or deceleration of the liver in response to the sudden stop of a crash. ${ }^{[10,12,13]}$ Moreover, an increase in the pressure of internal fluids due to a high speed crash was also suggested as a plausible cause of liver injury produced by BAT. ${ }^{[14-16]}$ In this study, lesions including crush, crack, and subcapular hematoma in the liver as complications of BAT were observed.

Taviloğlu et al. ${ }^{[17]}$ have found that liver is the most frequently injured organ in two hundred and fifty cases of BAT, and an injury of the liver occurs especially when trauma is from the right side.

Evaluation of one hundred and seven patients with BAT by Holmes et al. ${ }^{[18]}$ have revealed that the liver is damaged in forty-four out of 107 patients, while the spleen was injured in $4 \mathrm{I}$ individuals, and 5 patients had a GIS injury.

On the other hand, other studies have suggested that the spleen is the most frequently injured organ and the frequency of damage to the liver is less than to the spleen in cases of BAT. ${ }^{\left[{ }^{I I}\right]}$ Bruscagin et al. have also determined that spleen is the most frequently injured organ due to BAT. ${ }^{[14,19]}$ In this study, spleen is observed to be the second most frequently injured intra-abdominal organ.

Mortality rates due to liver injury vary between $5 \%$ to $25-$ $40 \%$ regarding the grade of injury. Mortality increases in highgrade liver injury. ${ }^{[19,20]}$
In parallel with previous findings, it was determined that injuries occurred most frequently in the liver. However, the grade of liver injury differed depending on the direction of trauma and fullness of the stomach. Liver is most likely to be damaged in rats if trauma came from the right and the stomach is empty. In agreement with previous studies, we also observed that an injury was most likely to occur in the right lobe of the liver. ${ }^{[11,19,20]}$

In cases with BAT, spleen injury commonly occurs due to trauma from the left affecting the chest. ${ }^{[21]}$ Due to high blood supply to the spleen, that is, $4 \%$ of cardiac output, hemorrhage causing death may be observed in spleen injury. ${ }^{[1-25]}$ In this study, intra-abdominal hemorrhage in more than half of the rats was observed to be parallel to previous studies. The results suggested that the spleen was the second most frequently injured organ. A plausible explanation for this could be that the rat spleen is anatomically linked to the tongue and it is more mobile compared to the human spleen.

Moreover, gastrointestinal injury is less frequent than solid organ damage in response to BAT. The damage rate to hollow organs due to BAT has been estimated as $6-10 \%{ }^{[25,26]}$ Different mechanisms play role in damage to organs including perforation of the organ from the effects of a crash and damage from crushing. ${ }^{[27,28]}$ Our observations revealed that injury to the GIS occurred as a crush rather than perforation.

Wessel et al. ${ }^{[29]}$ have conducted a study including three hundred and eight patients with BAT. Injury of the kidney was reported in sixty-seven cases and, moreover, 36 out of these 67 cases had grade 2 damage of the kidney. Our observations revealed that an injury in the kidney was most likely to be grade I or 2.

Furthermore, Shinkawa et al. ${ }^{[30]}$ have suggested that a full stomach may play a protective role on other intra-abdominal organs by absorbing the effects of the force produced by a crash like an air cushion, and this protective function may be more significant for the liver, especially when trauma comes from the left.

Intra-abdominal organ injury due to BAT was evaluated in this study and the results suggest that the liver is the most vulnerable organ in response to BAT, followed by the spleen and small intestine, respectively. Frequency and grade of intra-abdominal organ injury was higher in rats with empty stomachs. Considering the frequency of liver injury, the difference between Groups I and 6 as well as between Groups 2 and 6 was found to be statistically significant. Moreover, regarding spleen damage, the difference was also statistically remarkable in Group 3 compared to Group 6. Furthermore, GIS injury was higher in rats with a full stomach; however, the difference was not statistically significant.

Considering the low number of current experimental studies 
to evaluate BAT, it is our hope that this study will lead to further experimental studies.

\section{Conflict of interest: None declared.}

\section{REFERENCES}

1. Davis JH, Pruitt JH, Pruitt BA Jr. History. In: Mattox KL, Feliciano DV, Moore EE. Trauma. 4th ed. New York: McGraw Hill; 2000. p. 3-19.

2. Lyons AS, Petrucelli RJ. Medicine an illustrated history. New York: Harry Abrams; 1978.

3. Çakmakçı M. Travmaya genel yaklaşım. In: Sayek I, editor. Temel cerrahi. 3. basım, Ankara: Güneş Kitapevi; 2004. p. 351-8.

4. Minino AM, Heron MP, Smith BL. Deaths and death rates for the 10 leading causes of death in specified age groups: United States, preliminary 2004-Con. (Table 7). Nat Vital Stat Rep 2006;54:28-9.

5. Fingerhut LA, Warner M. Injury chatbook. Health, United States, 199697. Hyattsville, MD, National Center for Health Statistics, 1997.

6. TC Başbakanlık Devlet İstatistik Enstitüsü. 1990 yılı ulaşım ve trafik kazaları istatistikleri. 1991. s. 1-45.

7. Soysal Z, Çakalır C, Gürsel Ç. Adli tıp. 1. baskı, İstanbul Üniversitesi Cerrahpaşa Tip Fakültesi yayınları 1999. s. 549-54.

8. Wilkinson AE. Review of diagnostic methods in abdominal trauma. S Afr J Surg 1989;27:49-51.

9. Özel SK, Özel HB, Çolakoğlu N, Kazez A, Arslan N, Ozan E. Künt toraks travmasında gögüs kafesinin travma yönüne göre parankim koruyucu etkisi: Deneysel bir çalışma. 25. Ulusal Çocuk Cerrahisi Kongresi, 4-8 Kasım, Adana: 2006.

10. Benya EC, Bulas DL. Splenic injuries in children after blunt abdominal trauma. Semin Ultrasound CT MR 1996;17:170-6. CrossRef

11. Shkrum MJ, Ramsay DA. Forensic pathology of the trauma. Totawa: Humana pres; 2007. p. 405-510.

12. Erkin C, Taviloğlu K, Güloğlu R, Kurtoğlu M. Travma. 1. Baskı, İstanbul: İstanbul Medikal Yayınc1lı; 2005. s. 872-939.

13. Moore EE, Shackford SR, Pachter HL, McAninch JW, Browner BD, Champion HR, et al. Organ injury scaling: spleen, liver, and kidney. J Trauma 1989;29:1664-6. CrossRef

14. Moore EE, Cogbill TH, Jurkovich GJ, Shackford SR, Malangoni MA, Champion HR. Organ injury scaling: spleen and liver (1994 revision). J
Trauma 1995;38:323-4. CrossRef

15. Elhagediab AM, Rouhana SW. Patterns of abdominal injury in frontal automotive crashes. In: $16^{\text {th }}$ International ESV Conference Proceedings 1998. p. 327-37.

16. John TG, Greig JD, Johnstone AJ, Garden OJ. Liver trauma: a 10-year experience. Br J Surg 1992;79:1352-6. CrossRef

17. Taviloğlu K, Günay K, Şahin A, Ertekin C, Türel Ö. Gastrointestinal sistem travmalarına yaklaşım. Ulus Travma Derg 1995;1:126-34.

18. Holmes JF, Sokolove PE, Brant WE, Palchak MJ, Vance CW, Owings JT, et al. Ann Emerg Med 2002;39:500-9. CrossRef

19. Bruscagin V, Coimbra R, Rasslan S, Abrantes WL, Souza HP, Neto G, et al. Blunt gastric injury. A multicentre experience. Injury 2001;32:761-4.

20. Fabian TC, Croce MA, Stanford GG, Payne LW, Mangiante EC, Voeller GR, et al. Factors affecting morbidity following hepatic trauma. A prospective analysis of 482 injuries. Ann Surg 1991;213:540-8. CrossRef

21. Beal SL. Fatal hepatic hemorrhage: an unresolved problem in the management of complex liver injuries. J Trauma 1990;30:163-9. CrossRef

22. Doody O, Lyburn D, Geoghegan T, Govender P, Munk PL, Torreggiani WC. Blunt trauma to the spleen: ultrasonographic findings. Clin Radiol 2005;60:968-76. CrossRef

23. Brunsting LA, Morton JH. Gastric rupture from blunt abdominal trauma. J Trauma 1987;27:887-91. CrossRef

24. Nanji SA, Mock C. Gastric rupture resulting from blunt abdominal trauma and requiring gastric resection. J Trauma 1999;47:410-2. CrossRef

25. SalvadoJ,Lopez-espadas F, Varela A. Rotura ga' strica como complicacio'n del traumatismo abdominal cerrado. Med Intens 1977;1:51.

26. Buckman RF Jr, Piano G, Dunham CM, Soutter I, Ramzy A, Militello PR. Major bowel and diaphragmatic injuries associated with blunt spleen or liver rupture. J Trauma 1988;28:1317-21. CrossRef

27. Fischer RP, Miller-Crotchett P, Reed RL 2nd. Gastrointestinal disruption: the hazard of nonoperative management in adults with blunt $\mathrm{ab}$ dominal injury. J Trauma 1988;28:1445-9. CrossRef

28. Potoka DA, Saladino RA. Blunt abdominal trauma in the pediatric patient. Clin Ped Emerg Med 2005;6:23-30. CrossRef

29. Wessel LM, Scholz S, Jester I, Arnold R, Lorenz C, Hosie S, et al. Management of kidney injuries in children with blunt abdominal trauma. J Pediatr Surg 2000;35:1326-30. CrossRef

30. Shinkawa H, Yasuhara H, Naka S, Morikane K, Furuya Y, Niwa H, et al. Characteristic features of abdominal organ injuries associated with gastric rupture in blunt abdominal trauma. Am J Surg 2004;187:394-7. CrossRef

\section{DENEYSEL ÇALIŞMA - ÖZET}

\section{Midesi dolu ve boş sıçanlarda künt batın travması sonucu oluşan iç organ yaralanmalarının karşılaştırılması \\ Dr. Hüseyin Kafadar, ${ }^{1}$ Dr. Safiye Kafadar, ${ }^{2}$ Dr. Mehmet Tokdemir ${ }^{3}$}

${ }^{1}$ Adli Tıp Kurumu, Elazığ Adli Tıp Şube Müdürlüğü, Elazığ;
${ }^{2}$ Elazığ Özel Çağrı Tıp Merkezi, Elazığ;
${ }^{3}$ Fırat Üniversitesi Tıp Fakültesi, Adli Tıp Anabilim Dalı, Elazığ

AMAÇ: Bu çalışmada, midesi dolu ve boş sıçanlarda künt karın travması (KBT) sonucu karın organlarında yaralanma farklıı̆ı olup olmadığı, travmanın yönüne göre hangi karın organın daha fazla etkilendiği araştırıldı.

GEREÇ VE YÖNTEM: Literatürde kullanılacak travma kuvvetiyle ilgili veri bulunmadığından deneysel çalışmaya geçilmeden önce pilot çalışma yapıldı. Sıçanlarda ani ölüme neden olmayan ölçülebilir travma kuvvetini belirlemek amacıyla kurulan düzenekle $40 \mathrm{~cm}$ ve $45 \mathrm{~cm}$ 'den 200 gr. ve 250 gr. ağırlıklar sıçanların karın bölgesine isabet edecek şekilde serbest düşmeye bırakıldı. En uygun travma kuvveti ( $\mathrm{F}=69.978 \mathrm{~N})$ ve absorbe edilen enerji $(E=1 / 2 . m . v 2=0.979$ Joule), 40 cm'den bırakılan 250 gr ağılıkla elde edildi. Otuz altı sıçan çalışmaya alındı. Sıçanlara ketamin ile anestezi uygulandı. Midenin dolu ya da boş olmasına, travmanın önden, sağdan veya soldan gelmesine göre karın organlarında meydana gelen yaralanmalarda istatistiksel farklılık olup olmadı̆̆ı araştırıldı.

BULGULAR: En sık karaciğer, dalak ikinci ve ince bağırsakların üçüncü sıklıkta yaralandığı tespit edildi. Karaciğer ve dalak yaralanmaları açısından gruplar arasındaki fark anlamlı bulundu $(\mathrm{p}<0.05)$. Diger organ yaralanmaları açısından farklılık olmakla birlikte istatistiksel olarak anlamlı değildi. TARTIŞMA: Midenin dolu ya da boş olmasına ve travmanın yönüne göre karın içi organlarda farklılık olduğu tespit edildi. Anahtar sözcükler: Adli tıp; künt karın travması; sıçan; travma. 